ISSN 2080-1653

DOI 10.24917/20801653.331.7

\author{
MEHMET SAIT ŞAHINALP
}

Harran University, Sanliurfa, Turkey

\title{
Effects of Natural Geographic Features on the Manufacturing Industry in Sanliurfa, Turkey
}

\begin{abstract}
Geographical features of a place have an important effect on distribution, location, aglomeration and a variety of industrial activities. Social and economical features, along with natural geographic features such as geology, geomorphology, climate, natural vegetation, soil properties and hydrographic features also have a significant effect on industry. This study aims at determining how physical geographic features affect categories of industrial activities in Sanliurfa. For this purpose, firstly, physical geographic features of Sanliurfa and statistical data on agricultural and industrial activities in Sanliurfa were obtained. Then, effects of these physical features on other economic activities and the influence of those features on the distribution of industrial plants and industrial activities were analysed in terms of distribution, relation and casuality principles. Geological formations in Sanliurfa province occured in Neogene and also in Quaternary. These formations mostly consist of Neogene limestone, Quaternary basaltic volcanic rocks and alluvial soils. Geomorfically Sanliurfa is a slightly hilly place with plateaus and plains. The main river in Sanliurfa is the Euphrates - the biggest river of Turkey. Naural vegatation of Sanliurfa consists of steppe. These physical geographic fetaures of Sanliurfa cause intensive agricultural activites all across the province. Sanliurfa province covers $18,584 \mathrm{~km}^{2}$ and $60 \%$ of this area is convenient for agriculture. As a consequence, the majority of manucturing industry in Sanliurfa is agro-based, such as food, textile, mill and apparel industries. While these categories constitute $65.43 \%$ of all industrial enterprises, the share of enterprises involving stone, clay, glass, and concrete industry is $11 \%$, and lumber and wood industry share is only $2 \%$.
\end{abstract}

Keywords: geography; industry; natural environment; Sanliurfa; Turkey

Received: 27 November 2018

Accepted: 14 February 2019

\section{Suggested citation:}

Şahinalp, M.S. (2019).Effects of Natural GeographicFeatures on the Manufacturing Industry in Sanliurfa, Turkey. Prace Komisji Geografii Przemysłu Polskiego Towarzystwa Geograficznego [Studies of the Industrial Geography Commission of the Polish Geographical Society], 33(1), 89-105. https://doi.org/10.24917/20801653.331.7

\section{INTRODUCTION}

The main interest of industrial geography is to find out the relation between industrial activities and geographical environment that includes natural, social and 
economical features. The natural environment where all human beings carry out certain activities, has a strong and incontestable effects on social and economic life and it affects them drastically. Industrial activities, as part of economic environment, are mostly under the effect of natural environment, regarding concentration, variety of industrial plants, and raw material potential of space. Thus, geologic, geomorphologic, climate, hydrographic, natural vegetation, soil features of space, even risks of natural disasters determine the characteristics of industrial activities carried out in a given place. Natural environment creates both main resources of industry and other economic sectors which include industries such as agriculture, transportation, and commerce. The advantage of natural features such as favorable climate, abundance of agricultural lands, fertile soils, under/above ground wealth and proximity of major water sources play an important role in productivity and economic growth (Mill, 1909; Tümertekin, Özgüç, 1995). There is no doubt that there is a positive correlation between natural sources of a place and economic growth (Ricardo, 1951). Moreover, industrial and commerce policies of countries or local administrations, techonological infrastructure (Parkin, Esquivel, 1999; He, Zhu, 2001) and proximity to key marketing areas have a significant influence on the characteristisc of industry. Supply of labour, energy and capital play an important role in industry as well (Doğanay, 1995; Samuelson, Nordhaus, 2004; Kümmel, 2007).

The hypothesis of this research is based on the fact that industrial activities, particularly varieties of industry, are mostly formed by physical geographic features in Sanliurfa. This paper aims to find out direct or indirect impact of physical geographic features of Sanliurfa province on industrial activities. In fact, physical geographic features affect not only industry, but also other sectors of economy co-operating with industry by sustaining, supplying and providing resources. Modern industrialisation in Sanliurfa province started in the late 1990s. This movement developed as an agriculture-based industrialisation and still industrial plants in Sanliurfa are mostly agriculture-based. This situation brought many questions of why the industrial establishments are not more diverse and why the heavy industrial categories have not been developed in Sanliurfa. The main purpose of the present paper is to reveal the reasons behind industrial variation and with a geographical approach provide answers to the questions raised.

\section{Methodology}

In accordance with the purposes of this paper, statistical data about industrial enterprises, land use, and climate of Sanliurfa were obtained from relavant offical institutions such as Sanliurfa Provincial Directorate of Science, Industry and Technology, Karacadag Development Agency, The Chamber of Industry, Turkish Statistical Institute, Comerce of Sanliurfa, Directorate of Sanliurfa Organized Industrial Zone. The data about physical geographic features of Sanliurfa were also obtained from previous scientific studies. These features were shown by maps, graphs and tables. The data about industry and physical features of Sanliurfa were analysed by "distribution", "relation" and "casuality" principles of geography in order to illustrate the impact of natural environment on industry. 


\section{LOCATION OF SANLIURFA PROVINCE}

Sanliurfa is situated between latitudes of $37^{\circ} 42^{\prime}-36^{\circ} 40 \mathrm{~N}$ and longtitutes of $37^{\circ} 50^{\prime}-$ $40^{\circ} 13 \mathrm{E}$. Sanliurfa has is $18,584 \mathrm{~km}^{2}$ in surface and it is bordered by Mardin to the East, by Gaziantep to the West, by Adiyaman to the Northwest, by Diyarbakir to the Northeast, and Syria to the South. There are some geomorphic and hydrographic units which determine these provincial borders. For example, Sanliurfa shares the Euphrates River with Gaziantep as a border to the West and with Adiyaman to the Northwest. Sanliurfa also shares Mount Karacadag, which is a volcanic mass, with Diyarbakir to the northeast (Map 1, Map 3).

Sanliurfa is situated in a place that historically had a great strategic importance as it had been close to main commercial roads which linked Middle East to the Anatolia and Europe. It was an important commercial place where goods were sold or transferred among Mesopotamia, India, Iran, Northern and Western Anatolia and Europe until the 19th century. Today, although it has lost its previous importance regarding international trade, Sanliurfa still holds some roads that connect Southeastern Turkey and Middle East to the rest of Anatolia and Europe.

\section{General Natural Geographic Features of SAnliurfa Province}

\section{Geological Composition}

Geological features of Sanliurfa are characterised by Paleogene, Neogene and Quaternary formations and landforms. In terms of geological evolution, the Paleozoic era was stable in Sanliurfa like the rest of the Southeastern Turkey. In the large part of the Mesozoic era, this stability continued. Like the rest of the Southern Turkey, Sanliurfa was a sedimentation basin and covered by Tethys in Paleozoic and much of the Mesozoic era. The epeirogenic movement, starting at the end of the Mesozoic, was the first step of tectonic movements which shaped Southeastern Turkey and Sanliurfa. In this period, as a result of the collision that occured in the subduction zone of the Arabian and Eurasian plates, Arabian plate dove beneath the Anatolian plate and some crustal shortening and thickening started in southern Anatolia (Pamukçu et al., 2015).

Paleogene and Neogene eras were the most important phases in Southeastern Anatolia geological evolution since by the end of this era the whole region became a terrestrial area. In Eocene, as a consequence of marine sedimentation, silty limestone deposits occurred in the mid-eastern and western part of Sanliurfa. This formation was subsequently covered by upper Oligocene and lower Mioecene sedimentary deposits (Gürel et al., 2000). The extensional tectonics and compressional tectonics occurred in Miocene and in the following periods, resulted in some grabens like Akcakale and Suruc plains in Southern Sanliurfa (Tardu et al., 1987). Later on, these Miocene formations became detrition areas and older Eocene formations surfaced the large amount of Sanliurfa province, particularly the central and Western part of provincial land. The Karacadag volcanism which started in upper Miocene (Ercan et al., 1990) is important regarding the tectonic evolution of the region. By the end of the Oligocene, the collision of the Arabian plate with Anatolian plate cleared off unspoilt oceanic crust in Southeastern Anatolia. The following phase of this tectonic collision was terrestrial sedimentation, strike faulting and terrestrial volcanism along with the strike-slip fault 
Map 1. Map presenting the location of Sanliurfa

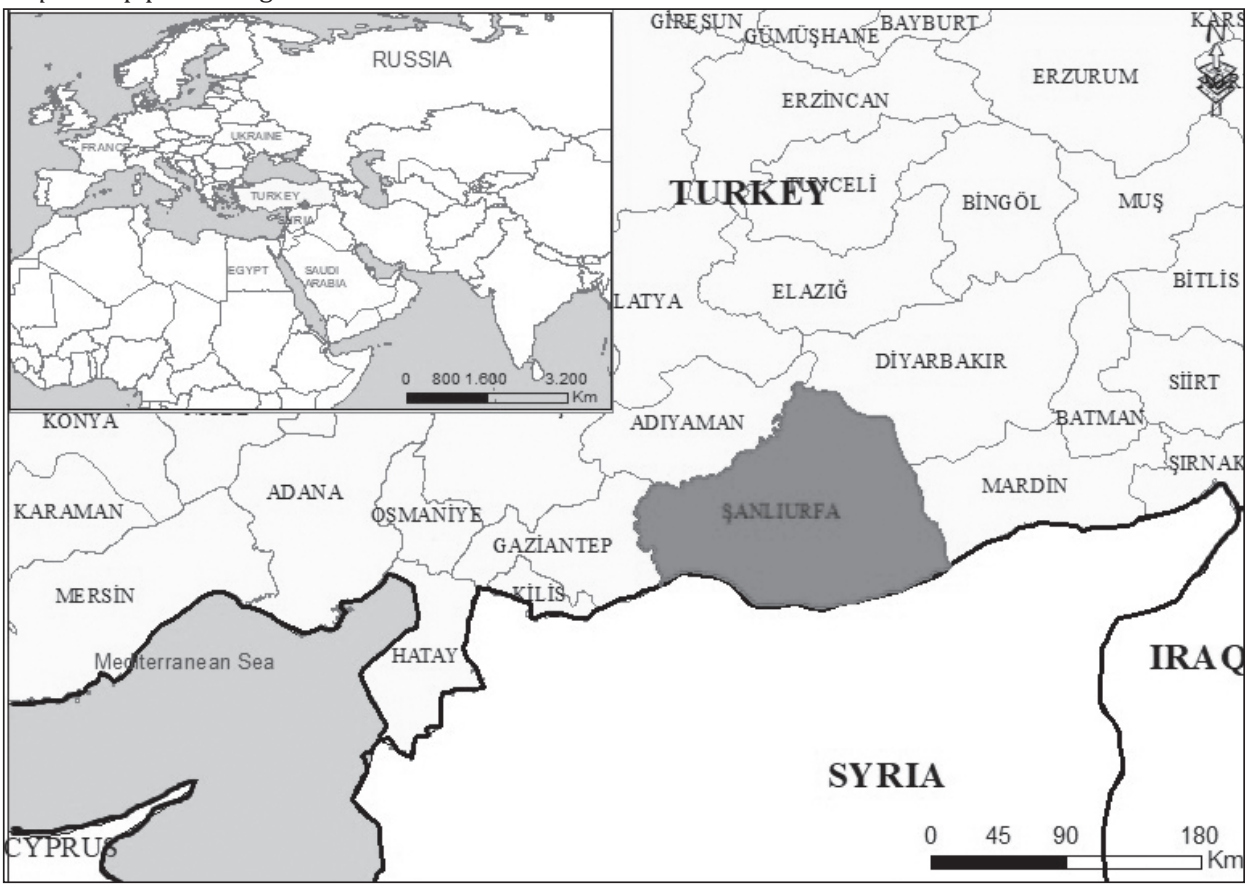

Source: 1:1,000,000 Political Map of Turkey

\section{Map 2. Geological map of Sanliurfa}

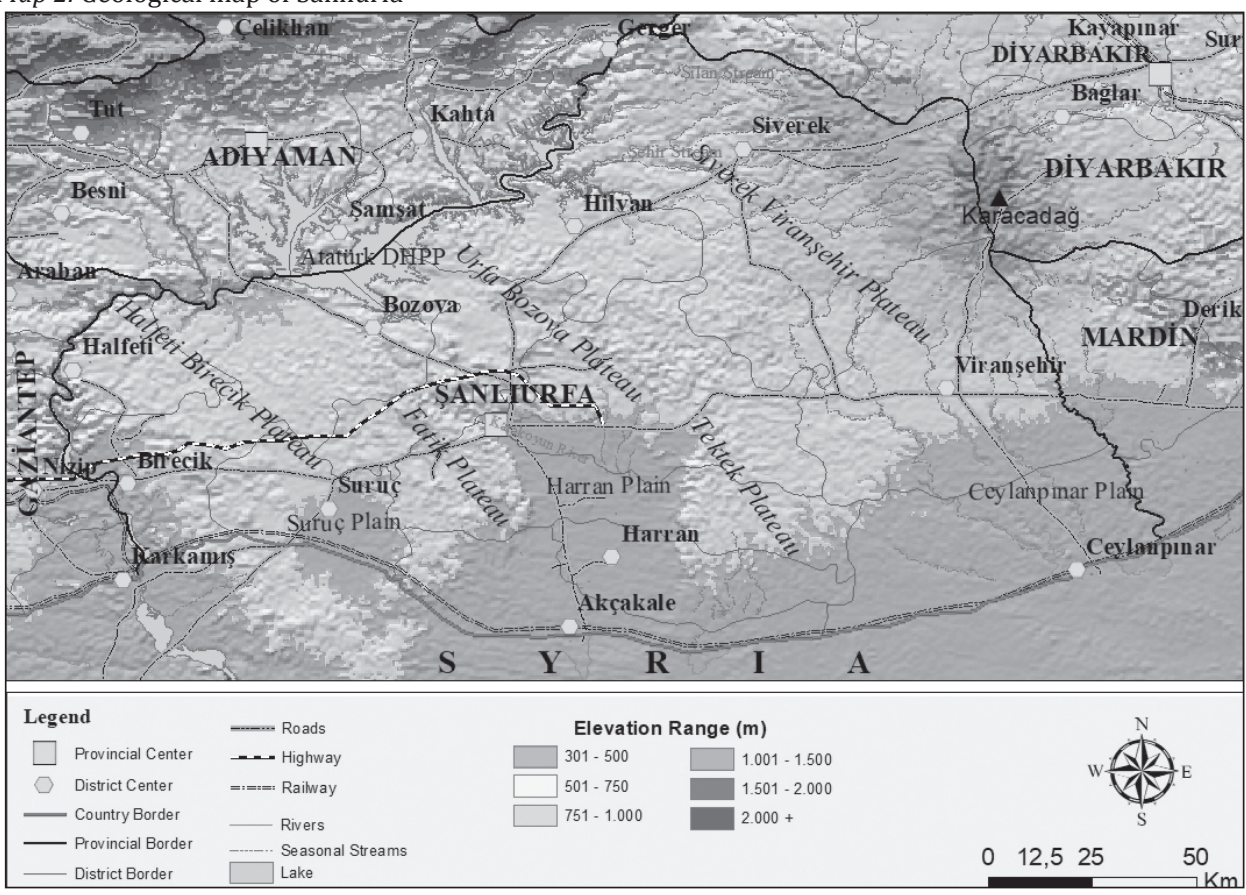

Source: 1:100,000 Geological Maps of Turkey 
lines in Karacadag (Okay, 2008). Akcakale and Suruc grabens situated in the South, and Karacadag extensional fissure in the Northeast of Sanliurfa have also tear fault character (Seyitoğlu et al., 2017). In late Pliocene, as a result of compression in convergence belt of Arabian and Anatolian plates, Southwest-Northeast trending Eastern Anatolian Fault Zone (EAFZ) occurred. The Bozova and Kalecik strike-slip faults in Sanliurfa are branches of EAFZ and both Northwest-Southeast trending faults are parallel to each other. Right lateral Bozova strike-slip fault also occurs in the west of the Akçakale/Harran graben (İmamoğlu, Çetin, 2007). Additionally, Pliocene is another significant era of detrition for provincial area which occurred over Eocene formations in the Northern Sanliurfa and Miocene formations in Southern Sanliurfa (map 2).

In Quaternary, plains characterised as grabens in the South of the province were covered by alluvial soils. Karacadag volcanism continued its activities from upper Miocene to early Quaternary. Mount Karacadag is a volcanic shield which occurred in three phases. The main shape of the volcanic mass occurred in the second phase of volcanic activity. The basaltic lawas, which flowed from Karacadag fissure system, spread over the large part of plateau in Sanliurfa. Thus, a considerable amount of plateau in Sanliurfa is covered by basaltic stones (map 2).

\section{Geomorphology}

The landscape of Sanliurfa province is inclined from North to South. Therefore, both the average elevation and amount of slope gradually increase from South to North. The average elevation to the Northwest of the province is 700 metres and increases to 1000 metres in the North. The elevation of Karacadag volcanic mass peak, sitiuated in the Northeast, is $1,938 \mathrm{~m}$, making it the highest point of the province. While average elevation in Western Sanliurfa is $400 \mathrm{~m}$, it increases to $700 \mathrm{~m}$ in central parts and then decreases to $600 \mathrm{~m}$ in Eastern Sanliurfa. The lowest average elevation of province is $350 \mathrm{~m}$ in the Southern part of the province where fertile plains lie along the Syrian border (map 3).

Sanliurfa's terrain does not consist of complex landforms. However, there are three main geomorphical units which are plains, plateaus and mountains trending East-West, and in echelon form from South to North. Ceylanpinar, Harran and Suruc plains characterised as grabens are also Turkey's important and fertile agricultural areas. These plains are also cut by Tektek and Fatik plateaus, trending North-South. In the North of this plain belt, it crosses to pleateu belt which is higher and comperatively more undulated. It is also cut by seasonal streams and enclosed by a hilly mountanious area in the North. These adjacent plateaus are named Birecik-Halfeti, Urfa-Bozova, Tektek, Fatik, Siverek-Viransehir (Benek, Şahinalp, Elmastaş, 2008; Günal, Şahinalp, 2017). Except for the Siverek-Viransehir plateau, which is covered by bazaltic lavas, the main structure of other plateaus are limestones. Therefore, some types of karst landforms such as labias, sinkholes, dolines and small poljes can be seen over these limestone-structrured plateaus (map 3).

The third main geomorphological unit is mountainous terrain that surrounds the province along the North and Northeast. This mountainous area mostly consists of Karacadag volcanic mass which is the highest elevation in the Sanliurfa (1,938 m) and placed between Sanliurfa and Diyarbakir. The drainage division of Karacadag determines the shared border between Sanliurfa and Diyarbakir (map 3). 


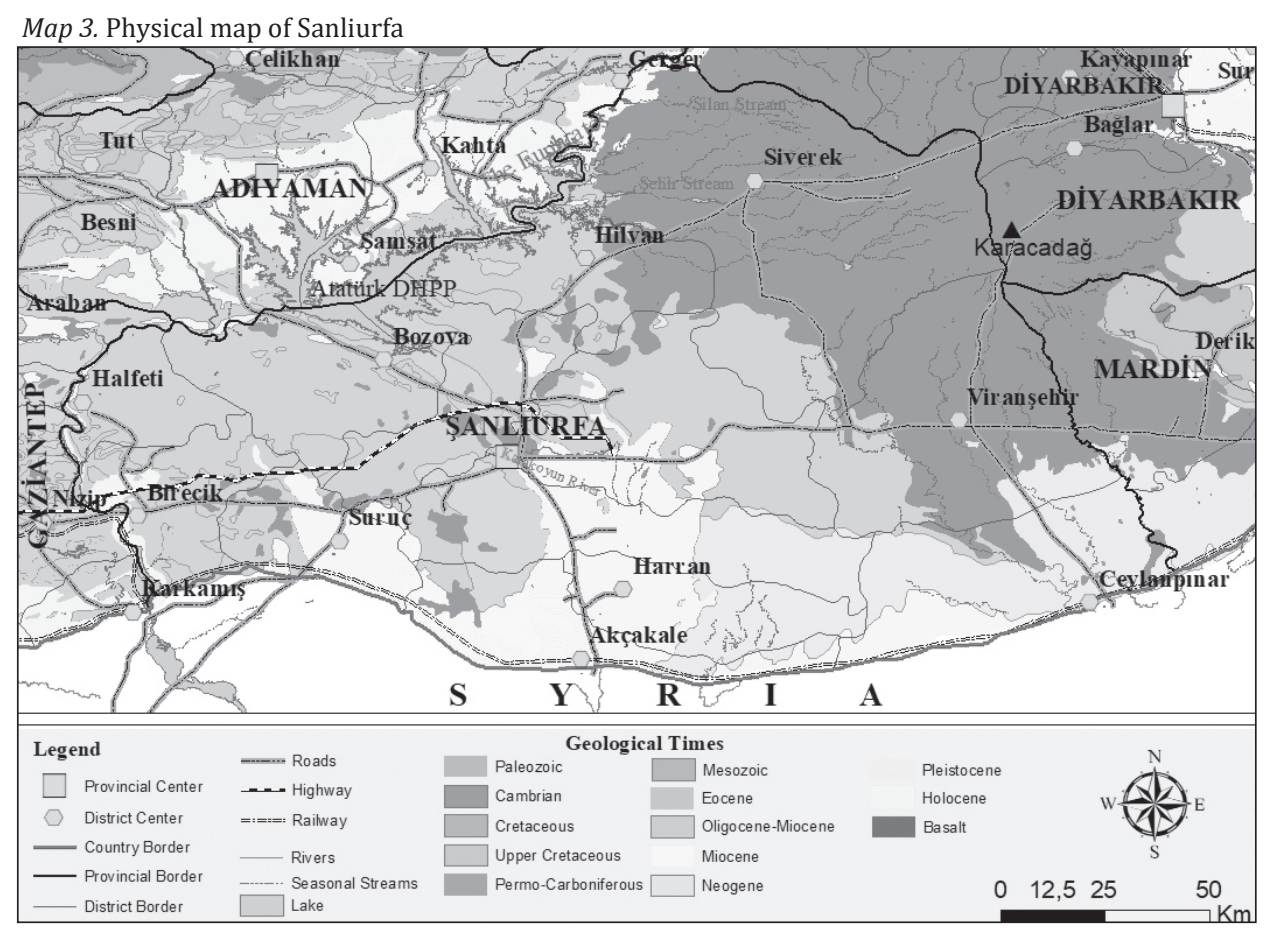

Source: Shuttle Radar Topography Mission (SRTM)

\section{Climate}

The province of Sanliurfa has a semi-arid climate due to its geographical location and landforms. This type of climate, in which summers are hot and dry and winters are comparatively cold and rainy, is defined as Continental Mediterranean or Mediterranean-Continental climate transition type. Sanliurfa province is the hottest place in Turkey in terms of average annual temperatures. The lowest temperatures are observed in the rainiest season and the highest temperatures are observed in the least rainy season.

Since the elevation increases from South to North, the average precipitation also increases from South to North, while average temperatures decrease from South to North. According to the statistics of Turkish State Meteorological Service (TSMS), the average annual temperature in Sanliurfa province is $17.5^{\circ} \mathrm{C}$ (Sanliurfa $18.3^{\circ} \mathrm{C}$, Siverek $16.3^{\circ} \mathrm{C}$ ). The average temperature of the summer season is $30.4{ }^{\circ} \mathrm{C}$ and the average temperature of winter season is $6.6^{\circ} \mathrm{C}$. In winter, the average temperature never falls below $0{ }^{\circ} \mathrm{C}$ (tab. 1, fig. 1 ).

The annual average rainfall in Sanliurfa is $426 \mathrm{~mm}$. The large amount of precipitation falls as rain all accross the province. Except for Northern part of Sanliurfa, the number of snowy days is very small. The duration of snow cover is also not too long, but this number increases from central part of Sanliurfa to the Northern part. Average annual precipitation increases from South to North (Ceylanpinar $317.2 \mathrm{~mm}$, Siverek 565.4 $\mathrm{mm}$ ) in accordance with the increase in elevation. The rainiest season in the province is winter and approximately half of the annual rain (48\%) falls during this season. The 
winter season is followed by spring (33\%) and autumn (16\%). The driest season of the year is summer $(3 \%)$ which is also the hottest season.

Tab. 1. Distribution of average temperatures and precipitation in Sanliurfa city

\begin{tabular}{|c|c|c|c|c|c|c|c|c|c|c|c|c|}
\hline & 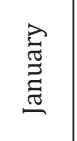 & $\begin{array}{l}\overrightarrow{0} \\
\overrightarrow{0} \\
\frac{0}{0} \\
\mathbb{0}\end{array}$ & $\begin{array}{l}\frac{5}{0} \\
\stackrel{\pi}{\pi} \\
\sum\end{array}$ & 胥 & $\stackrel{\vec{\pi}}{\Sigma}$ & $\stackrel{\Xi}{\Xi}$ & $\vec{\Xi}$ & 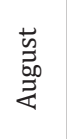 & 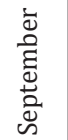 & $\begin{array}{l}\dot{\grave{d}} \\
\stackrel{0}{0} \\
\stackrel{U}{0}\end{array}$ & 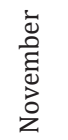 & 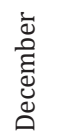 \\
\hline Avg. Temperature $\left({ }^{\circ} \mathrm{C}\right)$ & 5.4 & 7.1 & 10.9 & 15.6 & 21.3 & 27.0 & 31.1 & 30.6 & 26.4 & 19.9 & 12.9 & 7.6 \\
\hline Min. Temperature $\left({ }^{\circ} \mathrm{C}\right)$ & 1.4 & 2.6 & 5.5 & 9.4 & 14.2 & 19.6 & 23.5 & 23.1 & 18.9 & 13.2 & 7.3 & 3.4 \\
\hline Max. Temperature $\left({ }^{\circ} \mathrm{C}\right)$ & 9.5 & 11.6 & 16.3 & 21.9 & 28.5 & 34.5 & 38.7 & 38.1 & 33.9 & 26.7 & 18.5 & 11.8 \\
\hline $\begin{array}{l}\text { Precipitation Rainfall } \\
(\mathrm{mm})\end{array}$ & 86.0 & 72.0 & 70.0 & 51.0 & 32.0 & 4.0 & 1.0 & 0.0 & 2.0 & 28.0 & 45.0 & 85.0 \\
\hline
\end{tabular}

Source: MGM General directorate of Turkish meteorological service (2017)

Fig. 1. Distribution of average temperatures and precipitation fall in Sanliurfa city

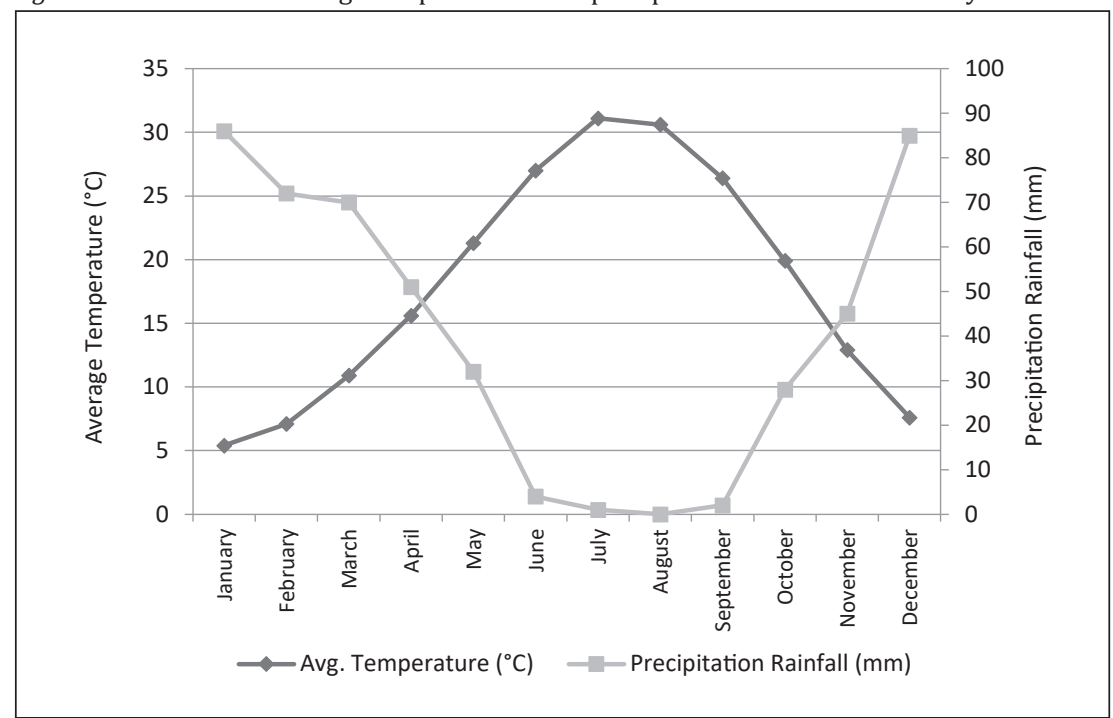

Source: MGM General directorate of Turkish meteorological service (2017)

\section{Soils}

There are different soil groups in Sanliurfa. These different soil groups, present within the boundaries of the province, were formed under the influence of geological, geomorphological and climate factors. There are four major soil groups in the province. They are red-brown soils, volcanic soils, brown soils, and alluvial soils.

The largest group of soils in the province is red-brown soils. These soils, which are the typical soil species of the Southeastern Anatolia Region, have been formed by the geological formation under the semi-arid climate conditions. Red-brown soils cover $66.3 \%$ of the province surface area. This soil group, except for the southern plains and the volcanic areas in the North and Northeast, is spread over a wide area, particularly in the plateaus (map 4). 


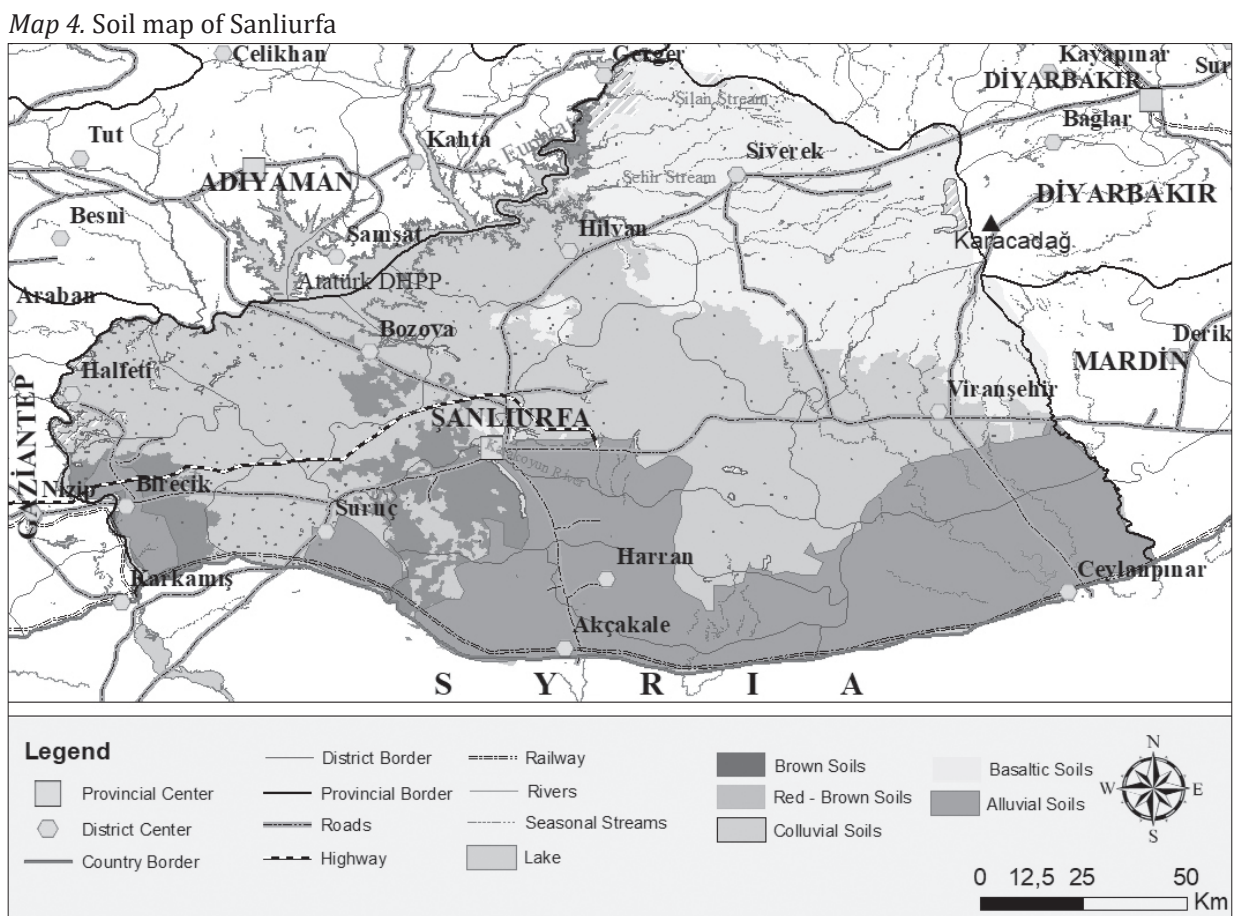

Source: 1:100,000 Map of Land Use and Suitability For Agriculture in Sanliurfa Province

The second largest soil group in Sanliurfa is volcanic soils. The vast majority of volcanic soils is situated in Siverek district and also in Viransehir and Hilvan districts. These soils, formed by the erosion of basaltic lava from the Karacadag volcanic system, are also found in the vicinity of Sanliurfa city and in the Northern part of Suruc district. This soil group constitutes $22.3 \%$ of the provincial soil groups (map 4).

The brown earth soils are generally seen in central areas of the province, in the Fatik Plateau and in the district of Birecik. This soil group constitutes $8.1 \%$ of the province's soils (map 4).

The last important soil group of the province is alluvial soils. Suruc, Harran and Ceylanpinar plains in the South are covered by these soils. These soils, which are extremely favorable for agriculture, constitute $3.4 \%$ of the soil groups found in the province (map 4).

\section{Hydrography}

Sanliurfa, situated in a semi-arid area, is disadvantaged in terms of the number of streams. The major river in Sanliurfa is the Euphrates which determines Sanliurfa's border with Gaziantep to the West and with Adiyaman to the Northwest. Having a length of 2,800 km, of which only $1,263 \mathrm{~km}$ is within Turkish borders, the Euphrates has $720,000 \mathrm{~km}^{2}$ drainage basin. Because of these characteristics, the Euphrates is the most important river of Sanliurfa and Turkey. The Atatürk Dam and Hydroelectric Power Plant, which was inaugurated in 1992, is situated on this river. In addition, Atatürk 
DHPP is the most important part of Souteastern Anatolia Poject (GAP) in terms of electricity generation and irrigation.

Other streams in Sanliurfa flow only in winter and spring. The principal streams of this group are Direkli, Karakoyun, Cavsak, Culap and Buyukdere, Celtik, Pinar, Pamuk, Zengecur, Aslanli, Karabag, Bahceli, Hamdun, Necarik, Titris, Zadeli, Giresav, Halfeti, Pınarbasi, Suleyman, Mizar, Kehriz, Germus, Aciksu and Mecrihan creeks.

There are no natural lakes in the Sanliurfa province. But the resorvoir of Ataturk Dam is the biggest pond in Turkey. Though an artifical lake which is $817 \mathrm{~km}^{2}$ in area, Ataturk Dam is the third biggest resorvoir after Lake Van and Salt Lake.

Another hydrographic feature of Sanliurfa is the aquifers. Throughout the province, there are two aquifer groups determined as upper and lower (Oldaç et al., 1972). As a consequence of geological evolution, the stratas are inclined from North to South. Thus the general flow direction of theses aquifer groups are from the highlands in the North to the lowlands in the South.

\section{Natural Vegetation}

Sanliurfa reflects the general characteristics of Souteastern Anatolia's natural vegetaiton. The Southeastern Anatolia region is situated in the Mesopotamian province of West Irano-Turanian Subfloristic Region in Irano-Turanian Floristic Region (Zohary, 1973). Apart from Irano-Turanian floristic elements, there are also Mediterranian and some Euro-Siberian (Eker et al., 2008) floristic elements in Sanliurfa. Like the rest of Southeastern Anatolia, the vast majority of Sanliurfa's natural vegatation consists of Irano-Turanian steppe. Relative location, climate, soil and topographical features of Sanliurfa have caused the emergence of steppe vegetation. This vegetation blossoms in winter and spring and typically dries out in hot and dry summers. As a result, there are no natural forests in Sanliurfa but there are some remnants of gall oak (Quercus infectoria) forests on the Karacadag volcanic mass. These degrated gall oak forests have been diminished as a result of ongoing deforestation over the past centuries.

\section{MANUFACTURING INDUSTRY IN SANLIURFA}

Manufacturing industry is defined as division D according to NAICS\&SIC (North America Industrial Classification System \& Standart Industrial Code) and coded between 20-39. Manufacturing division of industry involves processing raw materials and turning them into new product by using power-driven machines and equipments (https://www.naics.com/sic-codes-counts-division/?div=D). Establishments such as factories or plants use agricultural, forestry, mining, fishing and quarrying products as raw materials. These estalishments also use some semi-processed materials to make new products. According to NAICS (North America Industrail Classification System), there are 20 divisions of manufacturing industry. Yet major divisons of manfacturing industry are apparel, textile mill, food and kindred, chemical and allied, electric and electronical equipment, fabricated metal, machinery, lumber and wood, and stone-clay-glass-concrete.

Industrial establishments in Sanliurfa are mostly based on agricultural production. Leading sectors in manfacturuing industry in Sanliurfa can be categorised as "textile mill and apparel industry", "food and kindred industry", "industrial and commercial machinery and fabricated metal industry", "stone, clay, glass and concrete industry" and 
Fig. 2. Sectoral division of manufacturing industry in Sanliurfa

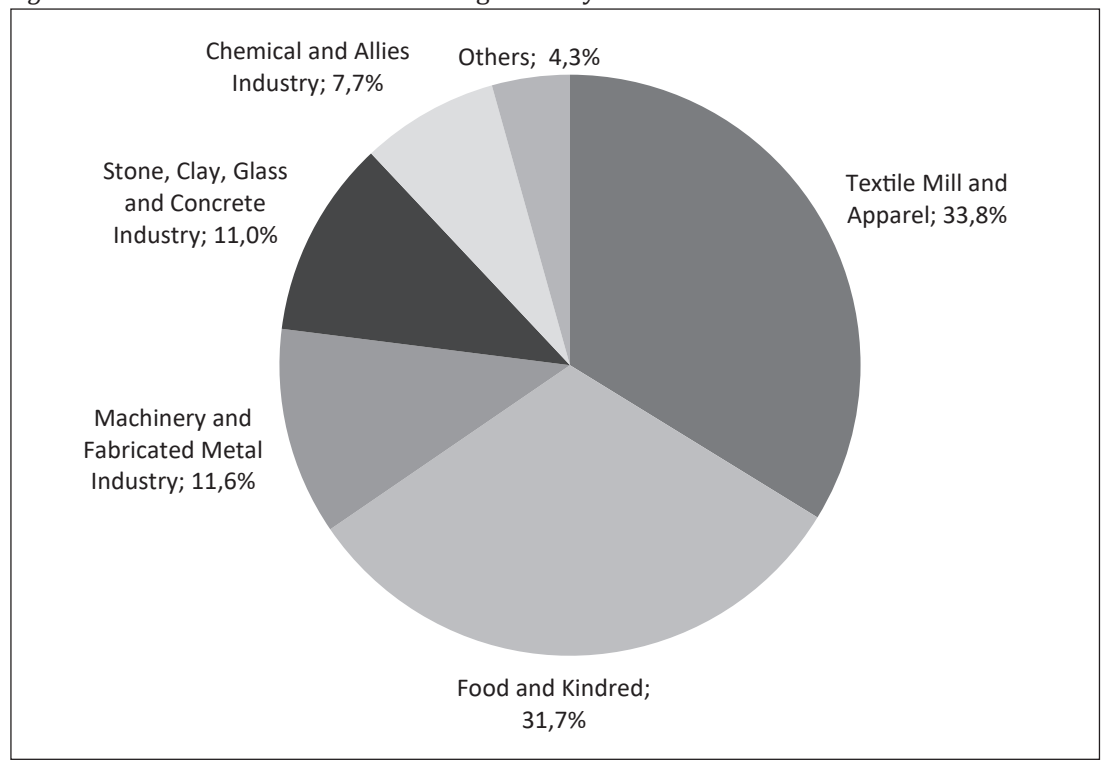

Source: Sanliurfa commerce and industry chamber (ŞUTSO) (2018)

"chemical and allied industry". The total number of establishments in manufacturing industry is 900 . The great majoritiy of industrial establishments consists of "textile mill and apparel industry" (33.77\%) and "food and kindred industry" (31.66\%). The share of both sectors constitutes $65.43 \%$ of the total number. In terms of their importance, other sectors are ranked as "industrial and commercial machinery and fabricated metal industry" (11.55\%), "stone, clay, glass and concrete industry" (11.00\%), and "chemical and allied industry" (7.66\%). The remaning industries' share is only $4.33 \%$ (fig. 2).

\section{Textile Mill and Apparel Industry}

Textile mill is the main raw material source of apparel products. As cotton and wool are used as raw materials in textile mill, impurities found in them must be removed. The process carried out in gining factories constitutes the first stage of textile mill production. The establishments in textile mill sector generally use cotton, wool and polyesteras as raw materials and transform them into yarn, cordage, braids, fiber, thread and twine. Weaving and knitting are other processes in textile mill to produce fabric. However, some products of textile mill need another process called finishing which is performed on the fabrics to improve their apperance and durability. Apparel industry involves producing clothing and accessories by cutting and stitching woven and knitted fabrics (https://www.naics.com/standard-industrial-code-divisions/?code=22; https://www.naics.com/standard-industrial-code-divisions/?code=23). Hence, apparel industry is based on textile mill industry and uses textile mill products as raw materials. Consequently, there is a strict connection between them.

Textile mill and apparel industry in Sanliurfa have the greatest importance when the whole manufacturing industry is considered. The number of establishments in these sectors is 304 (ŞUTSO, 2018; KKA, 2018) and it has a share of $33.77 \%$ of all industrial 
sectors. Except for a few esteblishments in Harran, Suruc, Viransehir and Siverek districts, most establishments in both sectors are situated in Sanliurfa Organized Industrial Zone. Between both industries, textile mill industry constitutes the vast majority of establishments. The number of establishments in this sector is 273 . This alone constitutes $30.33 \%$ of the whole manufacturing industry. However, 202 of 273 (73.99\%) textile mill establishments consist of ginning factories. This shows that the share of the establishments producing yarn, woven or knitted fabric, or performing the finishing process is dramatically low.

Apparel industry has not been developed as sufficently as it should have. Only 31 establishements are active in this sector and this number equals only $10.19 \%$ of the total share of both textile mill and apparel industries. Establishments in this sector involve the production of clothing, cushion cover, curtain and medical textiles.

\section{Food and Kindred Industry}

Establishments in this sector involve manufacturing or processing foods and related products for human and prepared food for animals and fowls (https://www.naics. com/standard-industrial-code-divisions/?code=20). Raw materials of this sector are agricultural and livestock products such as meat, eggs, and milk. Manufactured meat, dairy, canned/frozen/preserved fruits, vegetables and food specialties, grain mill, bakery, sugar, confectionery, fat and oils and baverages are main products of this sector.

Food and kindred industry is one of the prominent sectors based on agricultural production. Although Sanliurfa is one of Turkey's prominent agricultural production areas and agriculture is crucial for Sanliurfa's economical activities, food and kindred industry has not developed at an optimum level yet. Moreover, most of agricultural production obtained in Sanliurfa is not processed in the province. Some of this production is sold to different cities, while others are exported as raw material. Since hi-tech food production is not carried out, added-value gains are also at low levels. Despite the high number and share of these facilities, their profitability is quite low. They are mostly small and seasonal factories that generally produce bakery, processed vegetables and fruits, oil and fat, processed milk and milk products. Only Pinar, Turkey's leading milk brand, has a hi-tech facility in Sanliurfa.

The number of establishments included in this sector is 285 (ŞUTSO, 2018; KKA, 2018) and it constitutes $31.66 \%$ of the whole manufacturing industry. The establishments producing bakery products such as flour, semolina, pastry have the biggest share of food and kindred industry. The number of these establishments is 99 and it constitutes $34.73 \%$ of the sector. Other major categories are fat and oil (19.64\%), procesed vegetables and fruits (19.29\%), and milk and milk products (7.01\%).

\section{Industrial and Commercial Machinery and Fabricated Metal Industry}

Industrial and commercial machinery industry involves manufacturing different machineries and equipment for industrial and commercial use. Establishments involved in this sector manifacture different variety of machinery, from complicated machines to simple household machines, such as engines and tribunes, agricultural machinery, construction, mining machinery, engine related equipment, heating and cooling equipment, conveying and elevator equipment, commercial and service machinery, and other 
general-purpose machinery and equipment (https://www.naics.com/standard-industrial-code-divisions/?code=35). On the other hand, fabricated metal industry involves transforming metal into semi-finished or finished product, in particular, for industrial and commercial machinery industry. Main processes in this sector is forging, forming, bending and stamping, welding and assembling metal (https://www.naics.com/standard-industrial-code-divisions/?code=34; https://www.bls.gov/iag/tgs/iag332.htm).

Both industrial and commercial industry and fabricated metal industry are ranked in 3rd place in manufacturing industry regarding their numbers. The number of establishments in this sector is 104 (ŞUTSO, 2018; KKA, 2018) and it constitutes $11.55 \%$ of the whole manufacturing industry establishments. Major production in this sector consists of agricultural machinery and equipment such as plow, cultivator, seeder, and irrigation equipment, ginning machinery, food prosecessing machinery, elevator equipment, household equipment and hardware. In this sector, establishments manufacturing agricultural machinery and equipments have a share of $40.38 \%$, elevator equipment has $10.57 \%$, fabricated metal has $9.47 \%$, ginning and preserved food machinery has $6.73 \%$, and household equipment has 5.76\% share. As mentioned above, establishments in this sector mostly involve manufacturing agricultural machinery and equipment and agricultural product processing machinery and equipment. Thus, $46.75 \%$ of establishments (49) in this sector are related to agricultural production or manufacturing agricultural machinery and equipment. Although Sanliurfa has a notable agricultural production in Turkey, this sector which supplies agriculture and agro-based industry has not developed at an optimum level yet and it is still at an incipient stage.

\section{Stone, Clay, Glass, and Concrete Industry}

Main raw materials of this kind of industry are obtained from earth, depending on geological features of a place. Establishments involved in this sector use stone, sand and clay to manfacture cut stone, concrete and concrete products, glass and glass products and ceramics (https://www.naics.com/standard-industrial-code-divisions/?code=32). These products are used primarily to construct buildings, roads, bathroom fixtures and to produce porcelain.

Stone, clay, glass, and concrete industry is the 4th significant industrial sector of Sanliurfa. The number of these establishments is 99 (ŞUTSO, 2018; KKA, 2018) and constitutes $11.00 \%$ of the whole manufacturing industry. In this sector, limestone, bazalt stones, concrete, sand and clay are used as raw materials, Additionally, cut stones, bulding materials, pavement, ceramics and glass are manufactured. The vast majority of these establishments (97\%) involve manufacturing cut stones, cement, building and pavement materials and ceramics. The share of establishments that manufacture glass and glass products is only $3 \%$.

\section{Chemicals and Allied Industry}

Chemical industry involves chemical processing of raw materials obtained from earth or intermediates to produce primary chemicals such as acids, alkalies, salts and organic chemicals; as well as chemical products used in further manifacturing, such as plastic and rubber products, synthetic fiber, and finished chemicals for ultimate consumption 
such as drugs, cosmetics, detergents and agricultural chemicals (Chenier, 2002; Mesubi 2008; https://www.naics.com/standard-industrial-code-divisions/?code=28).

Chemicals and allied industry is one of the other incipent industrial sectors in Sanliurfa since it has not developed well yet. Therefore, products of this sector can be characterised as low value-added materials. The number of establishments producing chemicals and allied is 69 (ŞUTSO, 2018; KKA, 2018) and it constitutes only $7.66 \%$ of all manufacturing industry establishments. Thus, this sector is ranked 5 th with regards to its number of establishments. The widespread group in this sector includes establishments producing plastic and rubber materials, such as irrigation pipes and sprinkler, PVC windows and doors, plastic household materials. The number of establishments in this group is 41 and it constitutes $59.42 \%$ of chemicals and allied industry. The second major group in this sector is establishments producing soap, detergents and cosmetics. The number of establishments in this group is 8 and it constitutes $11.60 \%$ of the sector share. Another notable group in this sector is esablishments producing fertilizers, pesticides and vaccines for agricultural and veterinary use. The number of these establishments is 6 and it consists of $8.70 \%$ of the sector share. In addition, some data about this sector show that establishments manufacturing chemical product related to agriculture have also a noticable share. If the number of establishments producing fertilizers, pesticides and vaccines (6) are added to establishments producing irrigation pipes and sprinklers (14), it can be obviously seen that establishments producing chemicals and allied that are related to agricultural and veterinary use has approximetaly $29 \%$ share in the sector.

\section{Other Manufacturing Industries}

Except for manufacturing industry sectors mentioned above, there are two more insignificant sectors which are "furniture and fixtures industry" and "paper and allied industry". The total number of establishments involved in both sectors is 39 (ŞUTSO, 2018; KKA, 2018) and they constitute only $4.33 \%$ of the whole manufacturing industry. The number of establishments that involve manufacturing furniture and fixtures is 20 while the rest involves manufacturing paper and allied products.

\section{CONCLUSION}

In non-industrial areas, the characteristics of natural environment significantly affect the type of industrial activities and determine their character. For example, in Rize, it is the effect of natural features that have caused tea production to be a monoculture, and resulted in the emergence of tea processing plants. Likewise, in Batman, which has Turkey's main oil fields, petroleum refining and related industry has emerged. In Kastamonu, where the large majority of province is covered with forests, lumber and wood products industry has become apparent. As in these provinces, industrial activities in Sanliurfa have been largely affected by natural environment characteristics as well. The industrial sectors in Sanliurfa are based on extensive agricultural activities, as a consequence of natural environment characteristics.

Geological, geomorphological, climate, soil and hydrographic features of the province have produced extensive agricultural lands within provincial boundaries. Therefore, Suruc, Harran and Ceylanpinar plains in the South and the plateaus in the central 
and northern parts of the province have been used for agricultural activities throughout the history. The plains covered with alluvial soils and the plateaus mostly covered with red-brown soil resulted in fertile agricultural areas all accross the province. The climate features of the province also played an important role in agricultural activities. Semi-arid climate prevailing in the province facilitated various vegetable and fruit production, as well as the production of cereals. As of 2017, the total amount of areas which are convenient for agriculture in the province is 1,107,975.3 hectares. This amount of farmland constitutes $4.73 \%$ of Turkey's total agricultural land $(23,385,092.6$ hectares) (TUIK, 2017). Sanliurfa ranks third regarding the amount of agricultural areas after Konya and Ankara in Turkey. In this context, when the land use characteristics of the province are examined, it can be obviously seen that $60 \%$ of the province's land $(1,858,400$ hectares) is convenient for agriculture. On the other hand, the amount of the area excluding the agricultural areas, meadow-pasture and forest-heath lands, is $387,999.6$ hectares and it constitutes $21 \%$ of the province area (İÇDR, 2017).

The presence of the Euphrates, which is the most important river of Sanliurfa and Turkey, is another important feature resulting in an increase of agricultural products and productivity. With the opening of the Ataturk Dam and the Hydroelectric Power Plant, which were constructed within the scope of the Southeastern Anatolia Project, the range of irrigatied agriculture has increased. Agricultural irrigation had been first carried out in Harran Plain in 1995. Later, it was carried out in Bozova and Suruc districts. This situation led to changes in cropping pattern and increased the productivity of cotton in particularly. As of 2018, the agricultural areas of province which are convenient for irrigation are 934,549 hectares (11\% of all Turkey's irrigable land), Out of these, 433,830 hectares have still been irrigated (DSI, 2018, http://bolge15.dsi.gov.tr/ toprak-ve-su-kaynaklar\%c4\%b1).

In parallel with the increase in the agricultural productivity caused by irrigation, the first industrial facilities were established in Sanliurfa in first Organized Industrial Zone in 2000. Then, in 2009, Sanliurfa's second Organized Industrial Zone was established. By the end of the 1990s, industrial activities consisted of producing bulghur and flour. Later, lentil processing and ginning factories began to emerge. Thus, industrial activities, which had previously included manufacturing simple and primary products, began to diversify, increase in number and include higher value-added products.

Since the beginning of the new millenium, the majority of plants in manufacturing industry, which ammount to 900 , have mostly used agricultural products as raw materials. Of these 900 establishments involved in manufacturing industry, 33.77\% (304 units) use cotton as the basic raw material and manufacture weaving and textile products. Likewise, $31.66 \%$ (285 units) process grain, vegetables and fruits, and carry out activities in the food and kindred industry. On the other hand, the proportion of agrobased industrial estabishments is $65.43 \%$. Considering that $60 \%$ of the surface area of Sanliurfa is suitable for agriculture, it is seen that there is a direct correlation between the amount of agricultural areas and the share of industrial plants based on agriculture. In addition, $46.75 \%$ (49 units) of the machinery and metal industry sector manufacture cotton ginning, prepared food and agricultural machinery and irrigation pipes while $29 \%$ (20 units) of the establishments involved in the chemical and plastic industry sector manufacture agricultural pesticides, fertilizers, irrigation pipes and sprinkler systems. Accordingly, the total number of industrial establishments associated with agriculture is 658 , constituting $73.11 \%$ of all manufacturing industry. These data show 
how agricultural activities that developed as a result of the natural environment have a significant impact on the variety of industrial establishments in Sanliurfa.

Stone, clay and glass industry, which is one of the major industrial sectors in Sanliurfa, has been greatly affected by the geological characteristics of the province, too. This sector has a historical importance due to the construction of the traditional Sanliurfa houses. Cut limestone and basalt stones are used for traditional houses in Sanliurfa city and Siverek district. Besides, geological raw materials which are necessary for the production of cement, concrete, pavement and ceramics are supplied from limestone, basalt and clay dominated areas. Therefore, this sector, which has a share of $11 \%$ in the manufacturing industry, has developed under the influence of the natural environment as well.

Considering all these data given above, it can be obviously seen that the vast majority of the establishments in the manufacturing industry in Sanliurfa have been deeply affected by agricultural and geological characteristics of the province. According to these data, $84.11 \%$ of the establishments in the manufacturing industry in Sanliurfa have been shaped by the diversity that the natural environment provides. Consequently, features of natural environment have crucial influence on the diversity of industrial sectors and sort of manufactured materials in Sanliurfa where industrialisation has still been at an incipient stage.

\section{References}

Aral, I.O. (2008). Geology of Turkey: A synopsis. Anschnitt, 21, 19-42.

Benek, B., Șahinalp, M.S., Elmastaș, N. (2008). Şanlıurfa ilinde sulama tesislerinin arazi kullanımı bakımından yarattı̆̆ı sorunlar. V. Ulusal Coğrafya Sempozyumu. 5th National Geography Symposium. Ankara (16-17 October 2008), 61-70.

Canfei, H., Shengjun, Z. (2017). Industrial geography. In: D. Richardson et al. (eds.). International Encyclopedia of Geography, John Wiley \& Sons, Ltd. DOI: 10.1002/9781118786352.wbieg04. Industrial Geography | Request PDF. Retrieved from:https://www.researchgate.net/publication/307906868_Industrial_Geography, (2018/10/17,1-13).

Chenier, P.J. (2002). Introduction to the chemical industry: An overview. In: Survey of Industrial Chemistry. Topics in applied chemistry. Boston: Springer, 1-22.

Doğanay, H. (1995). Türkiye ekonomik coğrafyası. İstanbul: Öz Eğitim Yayınları.

Eker, İ., Koyuncu, M., Akan, H. (2008). The geophytic flora of Sanliurfa province, Turkey. Turkish Journal of Botany, 32, 367-38.

Ercan, T., Fujitani, T., Matsuda, J., Notsu, K., Tokel, S., Ui, T. (1990). Doğu ve güneydoğu Anadolu neojen-kuvaterner volkanitlerine ilișkin yeni jeokimyasal, radyometrik ve izotopik verilerin yorumu. MTA Dergisi, 110, 143-164.

Günal, V., Şahinalp, M.S. (2017). Coğrafi yapı ve tabiatın sunduklarıyla Şanlıurfa. In: M. Eriş, (ed.). Şanlıurfa. Şanlıurfa Valiliği Yayınları, 17-34.

Gürel, N., Teoman, M.Ş., Potoğlu, S., Ünsal, Y., Akbulut, İ., Turan, Y. (2000). Şanlıurfa ili yakın çevresinin arazi kullanım potansiyeli haritası projesi. Ankara: MTA Jeoloji Etütleri Dairesi.

İmamoğlu, M.Ş., Çetin, E. (2007). Güneydoğu Anadolu bölgesi ve yakın yöresinin depremselliği. D.Ü.Ziya Gökalp Eğitim Fakültesi Dergisi, 9, 93-103.

Kümmel, R. (2007). The productive of energy and its taxation. 4th European Congress Economy and Managers of Energy in Industry. Porto, Portugal, 27-30 November.

Mesubi, A.M. (2008). Chemical industry: An index of the technological development of a nation. Public Lecture Series, 19(19). Ota, Ogun State, Nigeria: Covenant University Press ISSN 2006$-0327$.

Mill, J.S. (1909). Principles of political economy. W.J. Ashley (ed.). London: Longmans.

Oldaç, T.Y., Eren, A., Türkman, M., Ertük, A. (1972). Harran ovası hidrojeolojik etüt raporu. Ankara: Enerji ve Tabii Kaynaklar Bakanlığı, Devlet Su İşleri Genel Müdürlügü. 
Pamukçu, O., Gönenç, T., Yurdakul Çirmik, A., Demirbaş, Ş., Tosun, S. (2015). Vertical and horizontal analysis of crustal structure in eastern Anatolia region. Bulletin of the Mineral Research and Exploration, 151, 217-229.

Parkin, M., Esquivel, G. (1999). Macroeconomía (in Spanish) (5th ed.). Mexico: Addison Wesley. ISBN 968-444-441-9.

Ricardo, D. (1951). On the principles of political economy and taxation. Cambridge: Cambridge University Press.

Samuelson, P.A., Nordhaus, W.D. (2009). Economics. 19th ed. New York: The McGraw-Hill Companies, Inc. ISBN 978-0-07-351129-0.

Seyitoğlu, G., Esat, K., Kaypak, B. (2017). The neotectonics of southeast Turkey, northern Syria, and Iraq: The internal structure of the southeast Anatolian wedge and its relationship with recent earthquakes. Turkish Journal of Earth Sciences, 26, 105-126.

Tardu, Y., Başkurt, T., Güven, A., Dinçer, A., Tuna, M.E., Tezcan, Ü.Ş. (1987). Akçakale grabeninin yapısal-stratigrafik özellikleri ve petrol potansiyeli. Türkiye 7. Petrol Kongresi Tebliğleri, 6-10 April, Ankara, 36-48.

Tümertekin, E., Özgüç, H. (1995). Ekonomik coğrafya. İstanbul: Çantay Kitabevi.

Zohary, M. (1973). Geobotanical foundations of the Middle East. 1-2. Stuttgart: Gustov Fisher Verlag.

\section{Govermental and Non-Govermental Institutions}

DSİ Devlet Su İşleri Genel Müdürlüğü (General Directorate of State Water Affairs) (2018). Irrigation projects. Retrieved from http://bolge15.dsi.gov.tr/toprak-ve-su-kaynaklar\%c4\%b1 (2018/10/30)

KKA Karacadag Kalkınma Ajansı (Karacadag Development Agency) (2018). Industry and manufacturing.

MGM Devlet Meteoroloji Geel Müdürlüğü (General Directorate of Turkish Meteorology Service) (2017). Meteorological data about Sanliurfa.

ŞÇŞiM Sanliurfa Çevre Şehircilik İl Müdürlüğü (Provincial Directorate of Environment and Urbanization) (2017). Sanliurfa ili 2016yll çevre durum raporu.

ŞUTSO Sanliurfa Ticaret ve Sanayi Odası (Şalıurfa Commerce and Industry Chamber) (2018). Data about industrial establishments in Sanliurfa.

TÜİK Türkiye İstatistik Kurumu (Turkish Statistical Institution) (2017). Agricultural statistics.

\section{Maps}

1:100,000 Geological Maps of Turkey, MTA Maden Tetkik Arama Kurumu (General Directorate of Mineral Research and Expolaration).

1:100,000 The Map of Land Use and Suitability For Agricultural in Sanliurfa Province, TKB Tarım ve Köy İşleri Bakanlığı (Agricultural and Rural Affairs Ministery).

1:1,000,000 Political Map of Turkey, HGM Harita Genel Müdürlüğü (General Directorate of Mapping).

NASA, Shuttle Radar Topography Mission (SRTM).

\section{Web Pages}

https://www.naics.com/standard-industrial-code-divisions/?code=20(Accessed 2018/10/31). https://www.naics.com/standard-industrial-code-divisions/?code=22(Accessed 2018/11/03). https://www.naics.com/standard-industrial-code-divisions/?code=23(Accessed 2018/11/04). https://www.naics.com/standard-industrial-code-divisions/?code=34(Accessed 2018/11/04). https://www.naics.com/standard-industrial-code-divisions/?code=35(Accessed 2018/11/04). https://www.bls.gov/iag/tgs/iag332.htm(2018/11/03).

Mehmet Sait Şahinalp, PhD, Harran University, Faculty of Arts and Sciences, Department of Geography. PhD in Human Geography. Associate professor. Academic member of the Harran University, Faculty of Arts and Sciences, Department of Geography (Sanliurfa-Turkey). Graduated from Marmara University. MA degree thesis "Geographical Etude and Planning of Harran Plain" was defended at Marmara University in 1998. PhD 
degree thesis "Establishmnet and Development of Sanliurfa City" was defended at Ankara University in 2005. Associate professor since 2014. Research interest: urban geography, economic geography, cultural geography, population geography.

\title{
ORCID: 0000-0001-8848-529X
}

\section{Address:}

\author{
Harran University \\ Faculty of Arts and Sciences \\ Department of Geography \\ Osmanbey Campus \\ 63050 Haliliye/Sanliurfa, Turkey \\ e-mail: sahinalp@harran.edu.tr
}

